\title{
COMPARISON OF QUALITY OF LIFE AMONG PATIENTS OF LUNG CARCINOMA TREATED WITH CHEMORADIOTHERAPY AND ACCELERATED RADIOTHERAPY
}

\author{
S. Rana ${ }^{1}$, R.K. Seam², M.K. Gupta ${ }^{3}$, M. Gupta ${ }^{2}$ \\ 1Post Graduate Institute of Medical Education and Research PGIMER, Radiotherapy and Oncology, Chandigarh, India. \\ 2Indira Gandhi Medical College -Shimla, Radiotherapy and Oncology, Shimla, India. \\ 3All India institute of Medical Sciences -Rishikesh, Radiation oncology, Rishikesh, India
}

\section{BACKGROUND}

Lung cancer is the most common cancer and the leading cause of cancer deaths worldwide. Non small cell cancer comprises of more than $80 \%$ of all lung cancer. The Standard of care for locally advanced non small cell lung cancer is CONCURRENT CHEMORADIOTHERAPY. Combined chemoradiotherapy for the management of locally advanced NSCLC, results in both acute (e.g., esophagitis, myelosuppression) and late (e.g., fibrosis) toxicity. Altered fractionation like accelerated radiotherapy is one of the untouched area in carcinoma lung . It shortens the overall treatment time, limits the accelerated repopulation with increased probability of tumour control and reduced late normal tissue toxicity.So we did this study to compare the quality of life in patients recieving accelerated radiation (six fractions per week) and conventional chemoradiation in locally advanced non-small cell luna cancer.

\section{Aims and objective}

To compare quality of life among patients treated with accelerated radiotherapy and conventional chemoradiotherapy .

\section{Material and methods}

Period of study :July 2015 to June 2016

Inclusion Criteria :-

- Previously untreated patients.

- Age $\leq 70 y r s$.

- Histology - Squamous cell ca, adeno ca, large cell ca, Adenosquamous ca .

- Unresectable or inoperable tumor.

- Normal renal and liver function tests.

- Karnofsky performance status $>70$.

Total 50 patients were enrolled in the study and were randomised into two arms using standardised randomization technique.

\section{Study design}

Control arm(25) : concomitant chemoradiotherapy Using cisplatin etoposide

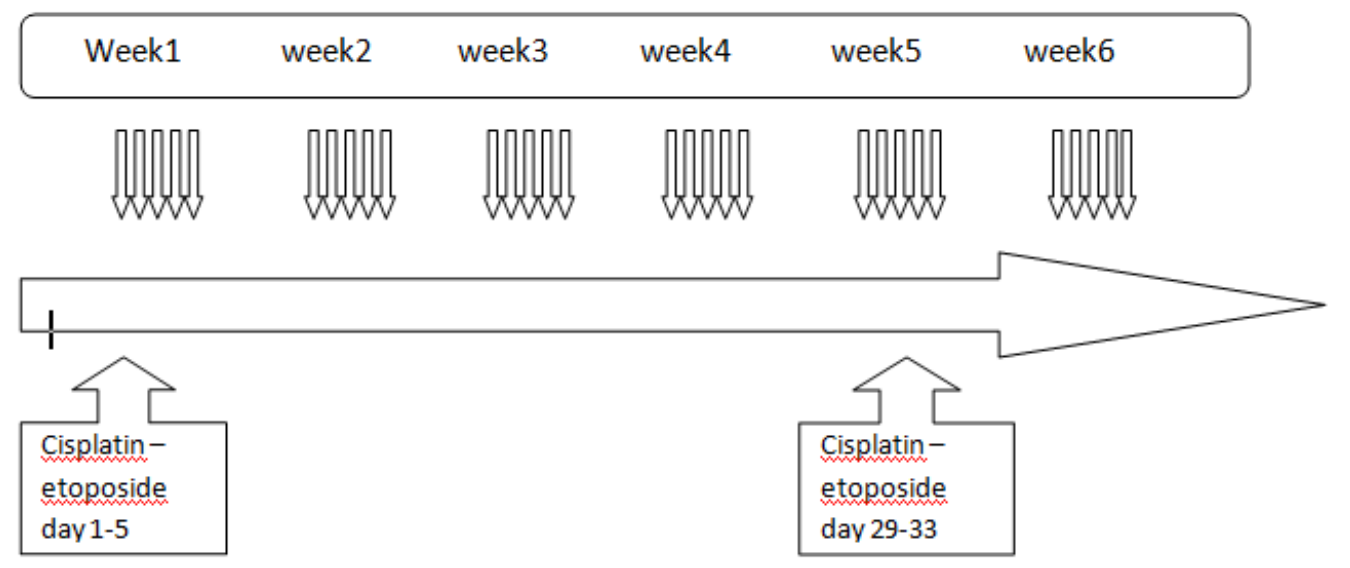

Study arm (25): accelerated radiotherapy

\begin{tabular}{|c|c|c|c|c|}
\hline Week1 & week2 & week3 & week4 & week5 \\
\hline מחתמת & תמת & מחת & מתח & מחת \\
\hline
\end{tabular}

\section{- Radiation}

Total dose of 60Gy / 30\# 2Gy/\# \& 6\#/week in 34 days ( 5 weeks).Spinal cord off after 44Gy.

Assessment : QOL assessment was done every week as per EORTC QOL -LC 13 and QLQ-C30 and at first follow up at 6 weeks .

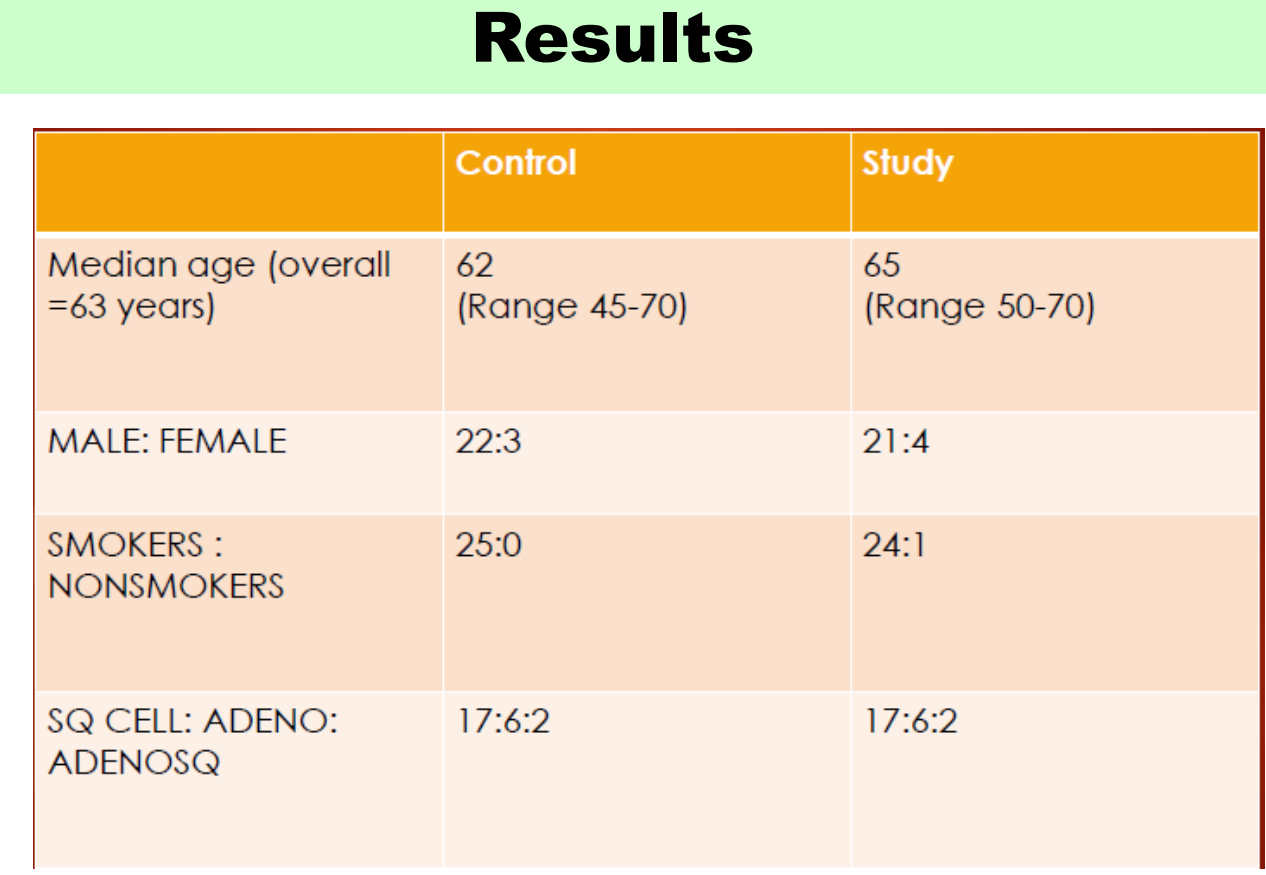

\section{Qol parameters improved}

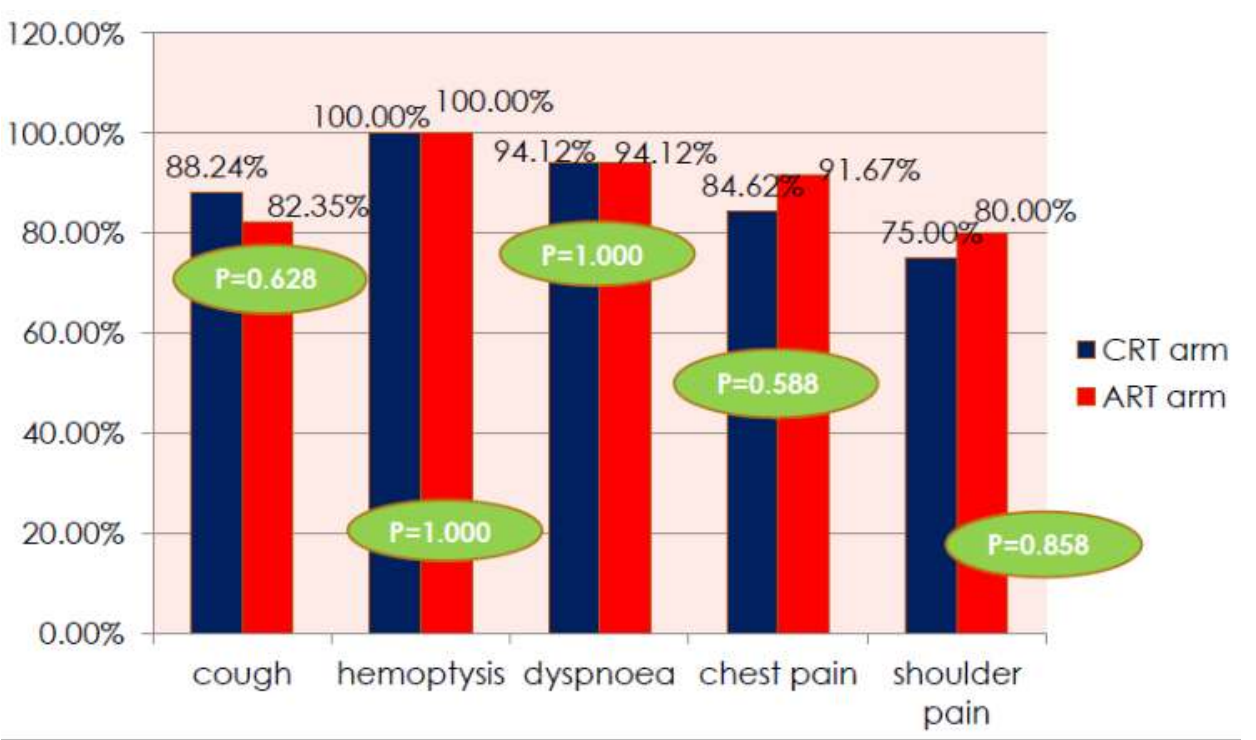

\section{Qol parameters worsened}

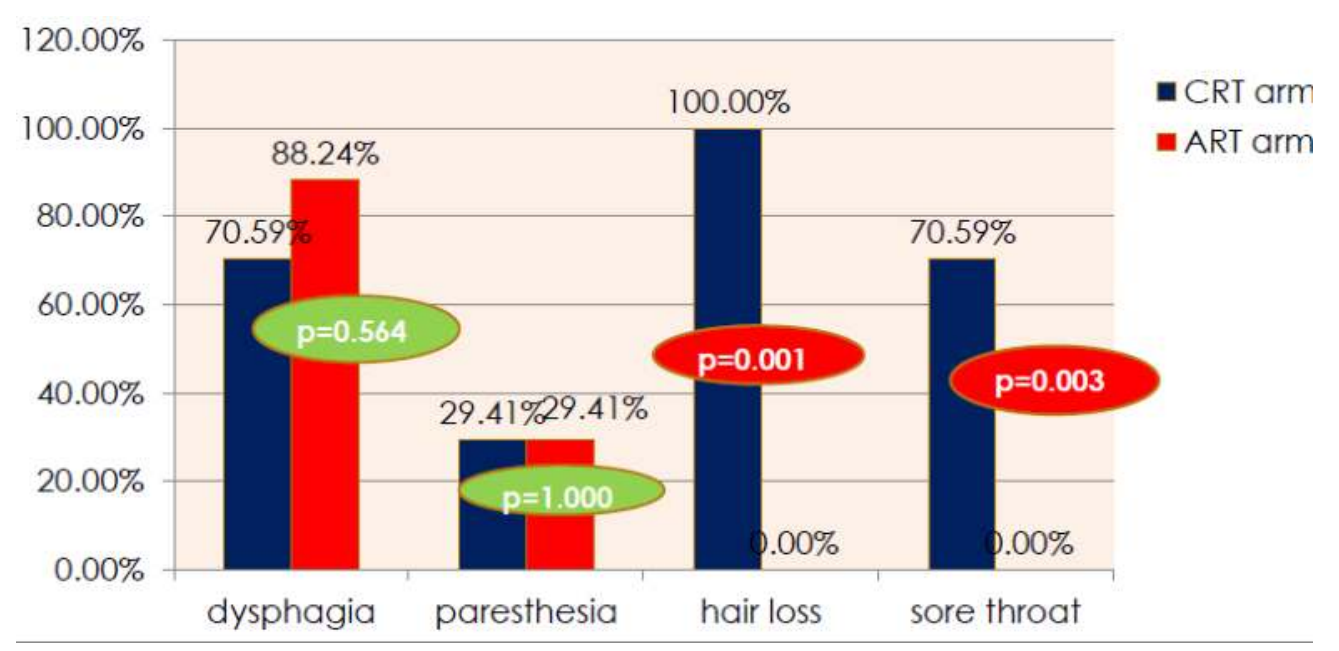

- Quality of life response rates in both the arm were excellent in hemoptysis(100\%), dyspnea (94\%)and chest pain(90\%).

- Quality of life worsen in hair loss and sore throat in conventional chemotherapy arm than in accelerated arm which was statistically significant.

- The greatest impairment was seen in global health status, followed by physical impairment and emotional functioning in both the arms

- There were relatively high levels of role, social, and cognitive functioning .

\section{Conclusion}

- A significant association was found between tumor response and palliation of hemoptysis,chest pain, arm/shoulder pain, and physical functioning.

- During radiotherapy, a significant increase for most general symptoms and a deterioration in functioning and QoL were noted.

- In accelerated arm, better quality of life in terms of symptoms and global health status was observed as compared to conventional chemoradiotherapy.

- Thus ART may prove a good alternate to concurrent CRT in lung cancer patients who are not a suitable candidate for CRT 